\title{
Uptake of multiple microinsurance schemes: evidence from Sri Lanka ${ }^{1}$
}

\begin{abstract}
Since it is common among households to use more than one form of microinsurance, this paper estimates the uptake of different kinds of microinsurance by the same population. We use a multivariate probit model, which examines the participation in the different forms of insurance simultaneously. By doing this, we can establish whether participation patterns in different types of microinsurance options indicates if the participation in specific insurance schemes is complementary or a substitute. We establish that membership of a microfinance institution means that households are more likely to have purchased an insurance policy. Furthermore, the study describes a need for more inclusive and composite packages of microinsurance products for greater financial inclusion of the poor.
\end{abstract}

Keywords: Microinsurance, Microfinance, Household Behaviour, Sri Lanka

JEL Code: G22, O16, R22

${ }^{1}$ The financial support for the research underlying this paper was provided by the British Academy (SG-44036) and we gratefully acknowledge the support of the Institute of Policy Studies of Sri Lanka (IPS) in carrying out the field survey. All errors are our own. 


\section{$1 \quad$ Introduction}

In recent years, the evolution of microinsurance as a risk-mitigation strategy has opened up choices for managing the vulnerability of low-income households. Using risk pooling in return for regular affordable premium payments, microinsurance schemes have responded to the limited and variable cash flows of low-income households, and their often uneven economic environment. In the literature, studies on micro health (e.g. Asfaw 2003, Bhat and Jain 2006, Jütting 2003, Ito and Kono 2010, Hamid et al. 2010), micro life (e.g. Giesbert et al. 2011; Arun et al. 2012), and on rainfall insurance (e.g. Giné et al. 2008, Giné and Yang 2009, Cole et al. 2009) have identified determinants of insurance participation in developing countries. A recent review (Eling et al., 2014) highlights the role of contract performance (including risk and quality), trust, financial literacy and informal risk-sharing mechanisms in expanding microinsurance markets. It is a common phenomenon that several households use more than one form of insurance, and this study identifies what affects a household's decision to take up micro life, health, vehicle or any other type of microinsurance. This paper contributes to the literature through an examination of different types of microinsurance which offer complementary and/or substitute alternatives, given budget constraints for households in Sri Lanka, and a simultaneous estimation of the patterns of actual usage, i.e. common and differing features, in different types of microinsurance. The findings of the study provide valuable insights for innovation in the product structure through the take-up of several classes of risk.

Furthermore, we establish that households which purchase insurance may have unobservable characteristics because of their membership of a microfinance institution (MFI), which - we argue - makes them more likely already to have purchased an insurance policy. Therefore, we limit the sample under study to those households whose members use at least one product/service from MFI, and estimate probit models to identify the determining factors of a 
household's insurance participation. When estimating the determinants of insurance uptake in this way there is scope for endogeneity, i.e. the decision to join the MFI is endogenous to insurance demand. Therefore, we use the estimates for comparison with the determinants of the participation in different types of insurance estimated in the multivariate probit models to test their conflicting or substitution outcome.

The outline of the paper is as follows: Section 2 discusses theoretical perspectives on microinsurance participation, followed by a discussion on data and methods, with descriptive statistics, in Section 3. Section 4 provides a discussion on estimates and Section 5 concludes.

\section{Theoretical Perspectives on Microinsurance Participation}

In a simple scenario, Giné et al. (2008) consider a model of insurance participation with symmetric information. The model assumes a risk-averse household with quadratic expected utility, i.e. consistent with a household with CARA (constant absolute risk aversion) utility facing normally distributed shocks (Mas-Colell et al. 1995, Giné et al. 2008). Based on these assumptions, it predicts that a household's willingness to pay for an insurance contract (i) increases if the household is more risk averse, (ii) increases with the expected insurance payout, (iii) increases with the size of the insured risks, and (iv) decreases with basis risks. Willingness to pay for security depends on the degree of risk aversion of the household; conversely, the uptake of insurance increases with the household's risk aversion. However, it is obvious that the uptake rate of microinsurance is still low, so that several households, for various reasons, remain uninsured against significant income risks.

Deviating from the simple yet full information model described above, adverse selection and moral hazard are often largely seen as potential explanations for barriers to insurance 
participation (Akerlof 1970, Rothschild and Stiglitz 1976, Browne and Doerpinghaus 1993, Cawley and Phillipson 1999). In the case of life or health insurance, the insurance-providing institution cannot fully determine whether an individual is at high or low risk of death. Although the national life expectancy and health status is public information, to observe these on a case by case basis requires a lengthy and inefficient use of time, costs and human resources. If the households have differential risks and do not charge a premium equal to the expected marginal cost of insurance, the possible adverse selection can lead to problems in the nature and patterns of participation in the microinsurance schemes.

Giesbert et al. (2011) find indications of adverse selection in micro life insurance participation. There is further evidence for the prevalence of adverse selection, as households having a higher ratio of sick members are more likely to purchase micro health insurance (Ito and Kono 2010). Adverse selection seems to be one reason, in combination with mistrust in the providers and unfamiliarity with insurance, for low take-up rates, high claim rates and low renewal rates. The providers are faced with difficult challenges in managing the incentive problems and simultaneously educating the poor. Incentive structures such as solidarity-enhancing rules seem to result in individual interests being restrained by group interests, whereas co-payment rules may be a strong deterrent to very poor households (Hamid et al. 2010). Moral hazard may also exist in the setting of microinsurance markets, if the household lives with less caution, risks more after contracting microinsurance, omits precautionary actions and overuses care; the last is a major problem, particularly for health insurance (Pauly 2004). In this paper, we test for the presence of adverse selection in micro life and health insurance participation in Sri Lanka.

To consider arguments from existing theoretical work on the demand for life insurance, we offer predictions from the model presented by Lewis (1989), which explicitly includes the preferences of the dependants and beneficiaries. This model posits the demand for life insurance as a 
maximization problem of the beneficiaries, spouse and offspring of the policy holder. The household's willingness to pay for life insurance will then (i) increase with the probability of the breadwinner's death, (ii) increase with the degree of risk aversion, (iii) increase in the present value of the beneficiaries' consumption, (iv) decrease with the policy loading factor, and (v) decrease with the household's wealth (Lewis 1989). From this model, we derive the outcome that the present value of the beneficiaries' consumption increases with the number of dependants within the household (Arun and Bendig 2010). A household's micro life insurance participation seems to be associated with the number of dependants, especially young dependants, and the marital status "being married", due to intended bequest motives expressing a "joy-of-giving" motive (Hurd 1987, Hurd 1994, Inkmann and Michaelides 2010). Further, we assume that participation in micro health insurance is positively linked to the household size, as household heads seem to have strong incentives to insure the entire household (Dror et al. 2007). In particular, female-led households are more likely to be enrolled in health insurance, reflecting the traditional role of women as the main health caregivers in the family (Khandker 1998, Chankova et al. 2008), so we control for this as well.

Both underlying models show an association between insurance participation and the degree of risk aversion. In the context of a developed country, there is evidence of a life-cycle effect on the degree of an individual's risk aversion in life insurance participation, although the latter decreases after a certain amount of wealth, income or age (Barsky et al. 1997). Therefore, it is plausible to assume that better-off households are better able and willing to bear a given amount of risk than are relatively poor households. For developing countries, there is evidence that risk-averse households are less likely to purchase an index-based, agricultural microinsurance (Giné et al. 2008) and that households who feel themselves more exposed to risk are less likely to use micro life insurance (Giesbert et al. 2011). This may explain why risky households, i.e. households who feel themselves more exposed to risk, have poorer access to insurance. Recently, Eling et. al 
(2013) examined the literature on microinsurance demand and compared it with evidence in the literature regarding traditional insurance markets. This study identifies the key factors affecting microinsurance demand, and further highlights the role of contract performance (including basis risk and quality), trust, financial literacy and informal risk-sharing mechanisms in expanding microinsurance markets. However, exposure to shocks has an influence on the use of insurance, although it differs for the tested risks (Giesbert et al. 2011, Bendig and Arun 2011a). Thus, we control for both the degree of risk aversion and previous risk exposure in our analysis.

\section{Data and Methods}

\subsection{Data and Summary Statistics}

The data for the analysis in this paper is based on a household survey conducted during 2007-08 in various villages covering all districts and regions in Sri Lanka. In total, 330 households were interviewed in 30 villages, drawn from two strata of (micro) insured and non-insured households, of which 240 households have and 90 do not have any insurance, including insurance policies offered by institutions other than the five MFIs listed below (see Arun et al. 2012 for further details). Households within each stratum (the insured and the non-insured households) were chosen through random sampling. The heads of the 240 insured households are members of an MFI, associated with one, and/or at least use some financial services, i.e. all 240 insured households are MFI members ${ }^{2}$. Of these, 142 households had purchased a life insurance policy, 29 health insurance, 62 vehicle insurance and 54 another type of insurance (Table 1). These insurance purchases are not exclusive, i.e. there are households which use more than one insurance type. The inter-dependencies or cross influences of one class of risk and others are a major concern and the credit life is dominant in the other insurance category in our sample.

\footnotetext{
${ }^{2}$ In our questionnaire we asked the households for the date of the insurance purchase or, in the case of loans, for the date of the loan disbursement. We have no comparable information for savings products and current accounts which are additionally offered by the MFIs. Therefore, we cannot provide comprehensive information on the duration of membership of an MFI.
} 
Table 1: Types and Distribution of Insurance under the Dependent Variable "Other Insurance" 3

\begin{tabular}{l|cc}
\hline Type of insurance & $\mathrm{N}$ & $\begin{array}{c}\text { Share (in } \\
\text { percentage) }\end{array}$ \\
\hline Life cycle insurance & 3 & 5.5 \\
Property insurance & 1 & 1.9 \\
Credit insurance & 37 & 68.5 \\
Age insurance & 8 & 14.8 \\
Other insurance & 5 & 9.3 \\
\hline Total & 54 & 100 \\
\hline
\end{tabular}

Source: Authors' calculation.

As a first step, the main suppliers of voluntary microinsurance for low-income households were identified in order to select the insured households (for a detailed account of the microinsurance sector in Sri Lanka, see Arun et al. 2011); see Table 2. The five MFIs are WDF, WDBF, Sanasa, Yasiru and SEEDS.

Table 2: Distribution across MFIs

\begin{tabular}{l|cc}
\hline Regions & N & $\begin{array}{c}\text { Share (in } \\
\text { percentage) }\end{array}$ \\
\hline WDF & 40 & 12.1 \\
WDBF & 65 & 19.7 \\
Sanasa & 65 & 19.7 \\
Yasiru & 64 & 19.4 \\
SEEDS & 96 & 29.1 \\
\hline Total & 330 & 100.00 \\
\hline
\end{tabular}

Source: Authors' calculation.

The total number of households - insured and non-insured - selected from the villages linked to the outreach of each of the five institutions varies from 40 to 96 . In total, only 40 households insured and non-insured - were linked to the villages and districts where WDF operates (i.e. Hambantota), while 95 households were associated with the outreach area of SEEDS, which operates throughout the country. 65 households were related to the areas covered by the other three institutions.

\footnotetext{
${ }^{3}$ The use of the insurance types covered under this category is not mutually exclusive.
} 
The survey sampling frame is a census of households across 30 villages covering all 14 districts (and the nine regions, Table 3) in which these MFIs operate.

Table 3: Distribution across Regions

\begin{tabular}{l|cc}
\hline Regions & N & $\begin{array}{c}\text { Share (in } \\
\text { percentage) }\end{array}$ \\
\hline West & 70 & 21.2 \\
South & 51 & 15.5 \\
Central & 69 & 20.9 \\
North Central & 25 & 7.6 \\
UVA & 45 & 13.6 \\
North & 15 & 4.5 \\
East & 15 & 4.5 \\
North West & 20 & 6.1 \\
Subura & 20 & 6.1 \\
\hline Total & 330 & 100.00 \\
\hline
\end{tabular}

Source: Authors' calculation.

Two or three MFIs were selected from each district, except for Vavuniya and Batticaloa, located in the Northern and Eastern provinces where only SEEDS is present, due to the high density of insured households. In total, the 30 villages selected are at least representative of all villages in which microinsurance is accessible via the selected MFIs. As microfinance is clearly concentrated in rural areas, the underlying survey is representative of villages in rural areas of Sri Lanka. We used the client bases of the five MFIs to select randomly the households for the insured strata. The selected number of households from each institution was allocated randomly across the districts in which they operate. In consultation with the district branch managers and respective staff members - to ensure a high density of insured households - we listed all eligible villages in the districts and then selected randomly from the list two or three villages in each district representing the selected MFIs in that district. 
The non-insured had to be randomly picked from the lists of households from existing CBOs (Community Based Organizations) in these villages; these are not exclusively associated with any of the five MFIs and have not purchased any insurance. The CBOs are used as a proxy sample for the non-insured group, according to limited financial resources for the survey. The noninsured group is therefore representative of non-insured households which are members in the covered types of $\mathrm{CBO}$. The $\mathrm{CBO}$ s selected are not involved in the microfinance activities of the microinsurance providers, but are involved, for instance, in community strengthening, infrastructure, health or economic issues beyond microfinance. For each village, one CBO was picked at random from a list of existing CBOs created with the help of the branch manager and the staff members of the MFIs in the district. From the selected CBO members, the households were randomly picked for the interviews. The number of insured and non-insured households selected from each village ranged from 10 to 15.

Table 8 (in Appendix) summarizes the definition of the variables in the estimates. We include different household characteristics, such as demographic and wealth variables, the level of education and economic activities of heads of households, information about remittances received by the household, the subjective risk assessment of the head, the household's previous risk exposure, and regional dummies. To avoid potential endogeneity problems, we constructed an asset index, which is controlled for so that none of the financial services contracted are used to purchase any asset. The index variable "risk assessment" is constructed from three questions using principal component factor analysis: one related to the household's self-perception of exposure to health shocks, weather and environment-related shocks; one related to economic shocks compared with neighbouring households; and one about the household's own rating of its willingness to take risks, using factor analysis ${ }^{4}$.

\footnotetext{
${ }^{44}$ The index is built by using a principal component factor analysis method using the following data points/questions described: The questions for the self-perception of exposure to health
} 
Sample characteristics are summarized in the descriptive statistics for insurance participation (Table 2) and for micro life, health, vehicle and other insurance participation (Table 3). The proportion of female households is higher among insurance non-buyers than among insurance buyers; only $17 \%$ of the households are female-headed. The share of female-headed households which participate in micro life, health or vehicle insurance is even smaller. Insurance buyers for all the types of insurance covered live in larger households, and among them is a slightly higher share of married household heads than among non-buyers. The ratio of ill household members is significantly higher among participants, especially in micro health, than among non-participants. Insurance buyers are significantly older than insurance non-buyers. Among the insurance buyers, the households own more land, have more remittance receipts, a lower share of uneducated, primary- or secondary-educated household heads, and a lower share of self-employed heads than among the insurance non-buyers. In Sri Lanka, insurance buyers belong to wealthier households than non-buyers (Bendig and Arun, 2011b). The households which have purchased any of the underlying types of insurance have a significantly higher risk-assessment index in Sri Lanka. A higher share of insurance and especially micro health insurance buyers had experienced the severe illness of a household member than was the case for non-buyers. The same is true for health insurance users in the case of experience of any other severe shock.

shocks, weather and environment-related shocks and economic shocks are, e.g. for health shocks: "In your opinion, is your household more or less exposed to health shocks/family related shocks compared to other households in your village?." The response categories are then (1) Much more, (2) A bit more, (3) About the same, (4) A bit less, (5) Much less. The question for the households' own rating of its willingness to take risks is: "How do you see yourself: Are you rather willing or unwilling to take risks? (Imagine a case, where at a certain cost you may receive a benefit, but which is not certain)". The households were asked to rank their willingness on a scale where the value 0 means "unwilling to take risks" and the value 5 means "willing to take risks". 
Table 4: Summary Statistics: Insurance Buyers vs. Non-Buyers

\begin{tabular}{|c|c|c|c|c|c|c|c|c|}
\hline \multirow[t]{2}{*}{ Variable } & \multicolumn{2}{|c|}{ Full Sample } & \multicolumn{2}{|c|}{ Insurance Buyers } & \multicolumn{2}{|c|}{ Insurance Non-Buyers } & \multicolumn{2}{|c|}{$\begin{array}{l}\text { Statistical Difference between } \\
\text { Insurance Buyers/Non-Buyers }\end{array}$} \\
\hline & Mean & Std. Dev. & Mean & Std. Dev. & Mean & Std. Dev. & Mean Diff. & Std. Dev. \\
\hline Female head & 0.169 & 0.376 & 0.163 & 0.369 & 0.189 & 0.394 & 0.026 & 0.047 \\
\hline Household size & 4.094 & 1.419 & 4.204 & 1.413 & 3.800 & 1.399 & $-0.404 * * *$ & 0.174 \\
\hline Married & 0.861 & 0.347 & 0.871 & 0.336 & 0.833 & 0.375 & -0.038 & 0.043 \\
\hline Ratio of ill household members & 0.393 & 0.414 & 0.409 & 0.419 & 0.349 & 0.401 & $-0.069 *$ & 0.051 \\
\hline Age & 47.88 & 11.70 & 47.41 & 11.53 & 49.12 & 12.14 & 1.714 & 1.446 \\
\hline Age squared & $2,428.7$ & $1,171.03$ & 2,379.9 & $1,134.54$ & $2,558.8$ & $1,260.58$ & 178.98 & 144.63 \\
\hline $\begin{array}{l}\text { Education of household head (base: } \\
\text { tertiary education) }\end{array}$ & & & & & & & & \\
\hline No or only primary education & 0.191 & 0.394 & 0.171 & 0.377 & 0.244 & 0.432 & 0.074 & 0.049 \\
\hline Secondary education & 0.409 & 0.492 & 0.40 & 0.49 & 0.433 & 0.498 & 0.033 & 0.061 \\
\hline $\begin{array}{l}\text { Occupation of household head (base: } \\
\text { formal employee/employer) }\end{array}$ & & & & & & & & \\
\hline Head is self-employed & 0.594 & 0.492 & 0.579 & 0.495 & 0.633 & 0.485 & 0.054 & 0.061 \\
\hline Head is unemployed & 0.221 & 0.416 & 0.221 & 0.416 & 0.222 & 0.418 & 0.001 & 0.051 \\
\hline Asset index & $-1.9 e-09$ & 1.000 & 0.126 & 0.985 & -0.337 & 0.967 & $-0.464 * * *$ & 0.121 \\
\hline Quintile 1 & 0.2 & 0.400 & 0.167 & 0.373 & 0.289 & 0.456 & 0.122 & 0.049 \\
\hline Quintile 2 & 0.2 & 0.400 & 0.179 & 0.384 & 0.256 & 0.439 & 0.077 & 0.049 \\
\hline Quintile 3 & 0.2 & 0.400 & 0.2 & 0.401 & 0.2 & 0.402 & 0 & 0.049 \\
\hline Quintile 4 & 0.2 & 0.400 & 0.221 & 0.416 & 0.144 & 0.354 & $-0.076^{*}$ & 0.049 \\
\hline Land ownership & 0.773 & 0.419 & 0.825 & 0.381 & 0.633 & 0.485 & $-0.192^{* * *}$ & 0.051 \\
\hline Remittance & 0.051 & 0.221 & 0.054 & 0.227 & 0.044 & 0.207 & -0.009 & 0.027 \\
\hline $\begin{array}{l}\text { Household's self-perception of risk } \\
\text { Household's risk experience (base: } \\
\text { no risk experience) }\end{array}$ & 9.9e-09 & 1.000 & 0.009 & 1.041 & -0.025 & 0.887 & -0.034 & 0.124 \\
\hline $\begin{array}{l}\text { Experienced death of a household } \\
\text { member }\end{array}$ & 0.073 & 0.260 & 0.071 & 0.257 & 0.078 & 0.269 & 0.007 & 0.032 \\
\hline $\begin{array}{l}\text { Experienced severe illness of a } \\
\text { household member }\end{array}$ & 0.142 & 0.350 & 0.158 & 0.366 & 0.1 & 0.302 & $-0.058^{*}$ & 0.043 \\
\hline Experienced other severe risk & 0.336 & 0.473 & 0.333 & 0.472 & 0.344 & 0.478 & 0.011 & 0.059 \\
\hline MFI member & 0.921 & 0.269 & 1.000 & 0.000 & 0.711 & 0.456 & $-0.289 * * *$ & 0.029 \\
\hline Observations & 330 & & 240 & & 90 & & 328 & \\
\hline
\end{tabular}

Source: Authors' calculation. Statistical differences are calculated with mean comparison tests (t-statistics). *** significant at 1 percent, $* *$ significant at 5 percent, * significant at 10 percent. 
Table 5: Summary Statistics: Life, Health, Vehicle and other Insurance Buyers vs. NonBuyers

\begin{tabular}{|c|c|c|c|c|c|c|c|c|c|c|}
\hline Variable & \multicolumn{2}{|c|}{ Full Sample } & \multicolumn{2}{|c|}{$\begin{array}{l}\text { Life Insurance } \\
\text { Buyers }\end{array}$} & \multicolumn{2}{|c|}{$\begin{array}{l}\text { Health Insurance } \\
\text { Buyers }\end{array}$} & \multicolumn{2}{|c|}{$\begin{array}{l}\text { Vehicle Insurance } \\
\text { Buyers }\end{array}$} & $\begin{array}{l}\text { Other Insurance } \\
\text { Buyers }\end{array}$ & $\begin{array}{l}\text { ance } \\
\text { Std. } \\
\text { Dev. }\end{array}$ \\
\hline Female head & 0.169 & 0.376 & 0.148 & 0.356 & 0.138 & 0.351 & 0.065 & 0.031 & 0.227 & 0.063 \\
\hline Household size & 4.094 & 1.419 & $4.296^{*}$ & 1.496 & 4.345 & 1.317 & 4.129 & 0.141 & 4.045 & 0.213 \\
\hline Married head & 0.861 & 0.347 & 0.880 & 0.326 & 0.931 & 0.258 & $0.984 * * *$ & 0.016 & 0.750 & 0.065 \\
\hline $\begin{array}{l}\text { Ratio of ill household } \\
\text { members }\end{array}$ & 0.393 & 0.414 & 0.397 & 0.409 & 0.413 & 0.376 & $0.529 * * *$ & 0.056 & $0.351 * *$ & 0.066 \\
\hline Age & 47.88 & 11.70 & 48.23 & 11.60 & 50.21 & 10.88 & 45.27 & 1.35 & $46.81 *$ & 1.80 \\
\hline $\begin{array}{l}\text { Age squared } \\
\text { Education of household } \\
\text { head (base: tertiary } \\
\text { education) }\end{array}$ & $2,428.7$ & $1,171.03$ & $2,459.9$ & $1,153.15$ & $2,634.9$ & $1,119.26$ & $2,161.0$ & 123.28 & $2,331.9 *$ & 179.7 \\
\hline $\begin{array}{l}\text { No or only primary } \\
\text { education }\end{array}$ & 0.191 & 0.394 & 0.183 & 0.388 & 0.241 & 0.435 & 0.065 & 0.031 & 0.205 & 0.062 \\
\hline $\begin{array}{l}\text { Secondary Education } \\
\text { Occupation of } \\
\text { household head (base: } \\
\text { formal } \\
\text { employee/employer) }\end{array}$ & 0.409 & 0.492 & 0.408 & 0.493 & $0.517^{*}$ & 0.509 & 0.290 & 0.058 & 0.432 & 0.076 \\
\hline Head is self-employed & 0.594 & 0.492 & $0.648^{* *}$ & 0.479 & 0.517 & 0.509 & 0.484 & 0.064 & $0.590 * *$ & 0.075 \\
\hline Head is unemployed & 0.221 & 0.416 & 0.218 & 0.415 & 0.207 & 0.412 & 0.226 & 0.054 & 0.227 & 0.064 \\
\hline Asset Index & $-1.9 \mathrm{e}-09$ & 1.000 & $0.180^{* * *}$ & 0.988 & 0.112 & 1.056 & $0.675^{* * *}$ & 0.097 & -0.079 & 0.156 \\
\hline Quintile 1 & 0.2 & 0.400 & 0.148 & 0.356 & 0.241 & 0.435 & 0.032 & 0.022 & 0.227 & 0.064 \\
\hline Quintile 2 & 0.2 & 0.400 & 0.176 & 0.382 & 0.069 & 0.258 & 0.161 & 0.047 & 0.181 & 0.059 \\
\hline Quintile 3 & 0.2 & 0.400 & 0.211 & 0.409 & 0.276 & 0.455 & 0.113 & 0.041 & 0.181 & 0.059 \\
\hline Quintile 4 & 0.2 & 0.400 & 0.190 & 0.393 & 0.138 & 0.351 & $0.274 * *$ & 0.057 & 0.227 & 0.064 \\
\hline Land Ownership & 0.773 & 0.419 & $0.845^{* * *}$ & 0.363 & 0.793 & 0.412 & $0.887^{* * *}$ & 0.040 & 0.750 & 0.066 \\
\hline Remittance & 0.051 & 0.221 & 0.056 & 0.231 & 0.069 & 0.258 & 0.048 & 0.027 & $0.068^{* * *}$ & 0.038 \\
\hline $\begin{array}{l}\text { Household's self- } \\
\text { perception of risk } \\
\text { Household's risk } \\
\text { experience (base: no risk } \\
\text { experience) }\end{array}$ & $9.9 \mathrm{e}-09$ & 1.000 & -0.054 & 0.878 & 0.086 & 1.143 & -0.029 & 0.132 & 0.120 & 0.177 \\
\hline $\begin{array}{l}\text { Experienced death of a } \\
\text { household member }\end{array}$ & 0.073 & 0.260 & 0.070 & 0.257 & 0.034 & 0.186 & 0.081 & 0.035 & 0.068 & 0.038 \\
\hline $\begin{array}{l}\text { Experienced severe } \\
\text { illness of a household } \\
\text { member }\end{array}$ & 0.142 & 0.350 & $0.190 * *$ & 0.394 & $0.345^{* * *}$ & 0.484 & 0.097 & 0.037 & 0.113 & 0.048 \\
\hline $\begin{array}{l}\text { Experienced other } \\
\text { severe risk }\end{array}$ & 0.336 & 0.473 & $0.373^{*}$ & 0.485 & 0.414 & 0.501 & 0.274 & 0.057 & $0.205^{* * *}$ & 0.062 \\
\hline MFI member & 0.921 & 0.269 & $1.000 * * *$ & 0.000 & $1.000^{* *}$ & 0.000 & $1.000^{* *}$ & 0.000 & $1.000^{*}$ & 0.000 \\
\hline
\end{tabular}

Source: Authors' calculation. Statistical differences are calculated with mean comparison tests (tstatistics) related to the non-participation subgroups (e.g. non-life insured). The significance level of the mean difference is presented via asterixes at the mean values, such as *** significant at 1 percent, ${ }^{* *}$ significant at 5 percent, ${ }^{*}$ significant at 10 percent. 


\subsection{Methodology}

A household's decision to buy insurance can be for different reasons. For instance, the law requires vehicle owners to have vehicle insurance. The signing of a credit life insurance is often required by respective MFIs for the approval of a credit application Therefore, we examine the actual usage of different types of (micro)insurance by households in Sri Lanka. When estimating the determinants of insurance uptake based on cross-sectional data, one encounters the important challenge of dealing with the problems of both endogeneity and self-selection (Jütting 2003). Therefore, we treat any implication of a causal relationship with caution and control as far as possible for potential endogeneity issues; thus, for instance, we apply an adjusted asset index. Household heads who self-select the insurance uptake may have unobservable characteristics related to preference or existing enrolment in an MFI - which make it more likely for them to participate in an insurance scheme (mainly offered by such MFIs) and which may influence their decision to use insurance (Waters 1999).

We apply a multivariate probit model for the use of different types of insurance, i.e. life, health, vehicle and other. Since preliminary analyses of our four outcomes of interest revealed that there may be a correlation between the different outcome categories and that the use of any one type of insurance is not exclusive (i.e. there are households who have more than one insurance type), we assume that households' choices of different types of insurance are interrelated. The multivariate probit model enables us to estimate four dichotomous dependent variables simultaneously, and to explicitly model the correlation in disturbance terms, using a method of simulated maximum likelihood. Therefore, we use it to estimate the determinants of the four different types of insurance, which is given by:

$$
\begin{array}{cl}
L^{*}=X^{\prime} \beta_{L}+\varepsilon_{L} & L^{*}=1 \text { if } L^{*}>0,0 \text { otherwise, } \\
H^{*}=X^{\prime} \beta_{H}+\varepsilon_{H} & H^{*}=1 \text { if } H^{*}>0,0 \text { otherwise, }
\end{array}
$$




$$
\begin{array}{ll}
V^{*}=X^{\prime} \beta_{V}+\varepsilon_{V} & V^{*}=1 \text { if } V^{*}>0,0 \text { otherwise, } \\
O^{*}=X^{\prime} \beta_{O}+\varepsilon_{O} & O^{*}=1 \text { if } O^{*}>0,0 \text { otherwise, }
\end{array}
$$

where $L^{*}, H^{*}, V^{*}$ and $O^{*}$ are the true, unobserved propensities to use life insurance, health insurance, vehicle insurance or any other insurance. The term $\mathrm{X}^{\prime}$ represents the vector of independent variables, i.e. the socio-demographic control variables. We assume that the distribution of the four outcomes is multivariate normal, i.e.:

$$
E\left[\varepsilon_{L}\right]=E\left[\varepsilon_{H}\right]=E\left[\varepsilon_{O}\right]=0 \quad \text { and } \quad \operatorname{Var}\left[\varepsilon_{L}\right]=\operatorname{Var}\left[\varepsilon_{H}\right]=\operatorname{Var}\left[\varepsilon_{O}\right]=1
$$

In multivariate probit models the computation of marginal effects is difficult. We therefore calculate the average partial effects (APEs) on the marginal probabilities of the independent variables for each equation by averaging sample partial effects.

To control for self-selection, we utilize a binary probit model to estimate the household's decision for insurance participation limited to the sub-sample of households enrolled in an MFI. We hypothesize that, after controlling for individual, household and regional characteristics, members of an MFI have better access to, and thus are more likely to use, insurance than are non-members. Therefore, we investigate the effect of the determinants of a household's use of insurance on the sub-sample of the households that were members of an MFI. In this way, our analysis is not faced with the problem of limited variance on the supply side, as all provinces and the five major microinsurance providers are covered in the underlying survey.

It is assumed that the insurance participation of a household (p) depends on the following factors: the wealth status of the household (w), characteristics of the household head $(\mathrm{H})$, household characteristics $(\mathrm{Z})$, regional characteristics $(\mathrm{R}) \mathrm{m}$ and on the error term $\mathrm{u}$, which is 
uncovariant with the other regressors. The following equation is applied to the model using the described sample structure:

$$
p_{i}=f\left(w_{i}, H_{i}, Z_{i}, R, u\right)
$$

In order to estimate the probability of participation, we use a binary probit model:

$$
\begin{aligned}
& p_{i}^{*}=\beta w_{i}+\alpha H_{i}+\phi Z_{i}+\delta R+u_{i} \\
& p_{i}^{*}=1 \text { If, meaning the household I is a member of a MFI (equation 1) or uses } \\
& \text { insurance (equation2), } \\
& p_{i}^{*}=0 \text { Otherwise. }
\end{aligned}
$$

\section{Estimating the Participation Patterns of Different Microinsurance Schemes}

The results of the multivariate probit regressions for the analysis of a household's insurance participation decision, i.e. what determines the use of micro life, health, vehicle and other forms of insurance, are presented in Table 5 and in Table 9 (in Appendix) showing the APEs of the explanatory variables on the marginal probability of using the different types of insurance. Two model specifications have been estimated for each dependent variable and estimation: the first one includes, among the other regressors, an asset endowment index as a continuous variable and the second uses dummies for asset endowment quintiles. Further, we calculated marginal effects for two reference ${ }^{5}$ households: (1) a female-headed household which has eight household members, a head of household aged 45 years with no formal or only primary education, but selfemployed, with an asset endowment index of zero, without any land, who receives remittances, has a risk assessment index of one, has experienced a death, the illness of a household member and an additional shock in the past five years; and (2) a male-headed household which has four

\footnotetext{
${ }^{5}$ It is important to note that it may be better to create a benchmark value - a reference case - for which the marginal effects are calculated (Cameron and Trivedi 2009). The reference households were chosen to display two different, but typical household configurations. The first one is seen as the "highly vulnerable" reference household as its attributes include a female head with low educational attainment, small asset endowment and high exposure to risk. Household (2) is assumed to be the reference for a "less vulnerable" household as its characteristics include smaller size, higher educated head and higher asset endowment than its counterpart in reference (1).
} 
household members, a head who has attained secondary education, an asset endowment index of two, without any remittances and, for the other variables, the same outcomes as the first reference household. Two explanatory variables - namely married head and the ratio of ill household members - are included here according to the relevance of bequest motives, particularly for micro life, and adverse selection for micro life and health insurance.

It is important to note that the four outcome categories, i.e. the types of insurance, are not mutually exclusive. The estimated correlation coefficients, listed at the bottom of the tables, indicate that the residuals of the four outcome categories are correlated. Two of the estimated correlation coefficients are negative and statistically significant for Sri Lanka. The correlation coefficient between the unexplained part of the use of micro health and vehicle insurance amounts to -0.33 and between micro vehicle and other insurance to -0.68 , suggesting that there exist unobservable characteristics of the household that influence the household's decision to purchase health or vehicle insurance, and likewise vehicle or any other form of insurance. This outcome shows that from the household's perspective the participation in health or vehicle and vehicle or any other form of insurance are conflicting alternatives. Furthermore, it suggests that households who buy health insurance are also more likely to buy life insurance. This might be related, for instance, to private information associated with their mortality risk (or at least to unobserved covariates correlated with mortality risk, or the household's perception of mortality risk).

In line with the literature, female headship of a household is positively associated with the use of micro health insurance in Sri Lanka, which may reflect a higher incentive to provide security, especially health care, to the household compared with male-headed households. This is confirmed by the fact that women are the main health caregivers in the family, a traditional role; thus, they prioritize more health-related expenditure for the family than do men, including the 
premium paid to a micro health insurance scheme. Nevertheless, it is important to note that women are often the main target group of specific microcredit programmes, and thus more likely to contract micro health insurance.

From the predictions of the model for life insurance demand, we expected a positive relationship between household size and the participation in micro life insurance due to bequest motives. Indeed, we find a positive association for micro life insurance. In our first specification, household size, indicating the number of dependants in the household, is an economically and statistically significant predictor of micro life insurance participation due to an intended bequest motive (Arun et al. 2012). However, we find no significant relationship between micro life insurance participation and the marriage status of the head as the other possible bequest-related determinant. Nevertheless, the outcome shows that being married is significantly positively linked to the uptake of micro health and vehicle and negatively related to the use of any other form of insurance. Most notably, married household heads - similar to female-headed households - seem to have a higher propensity to internalize the costs and consequences related to health shocks and related care than have unmarried heads.

In line with earlier findings in the literature, we find a significant positive outcome for the ratio of ill household members to participation in micro life and vehicle insurance. In the case of health insurance, the existence of adverse selection is not evident here, which might be related to the fact that this insurance type does not cover pre-existing conditions, or that households with many sick members may not be able to afford the up-front premiums. In addition, we find the right sign (though not statistically significant) for the covariate covering households experiencing a severe illness $(z=1.42)$. Instead, the death of a household member is actually predicting a higher probability of health insurance purchase, which is consistent with adverse selection, 
assuming that mortality risk is correlated within the family, and that the death is preceded by illness.

Further, our results show no life-cycle effect for any of the four insurance types, which indicates a U-shaped age pattern for Sri Lanka. There is significant evidence for such an age pattern for micro life participation, health and vehicle insurance. It appears that household heads are less willing to pay for insurance up to a specific age, after which their willingness increases due to higher incentives to protect their families from certain hazards.

Deviating from the underlying theoretical model of Lewis and the bulk of the literature, we find that household heads with no formal, only primary or secondary, education are significantly more likely to buy life and health insurance than heads with tertiary or higher education. This implies that heads of households with a lower level of education are not excluded from microinsurance participation and are not less willing to pay for it than are highly educated heads. In contrast to the findings of Chankova et al. (2008) and Ito and Kono (2010), our results imply that the concept of micro health insurance is also capable of being understood by the less well educated heads. Moreover, we find that these households may have lower income-earning opportunities, so that they may have higher incentives to secure their families against the negative outcomes of certain shocks, such as death or sickness. We agree with previous contributions in the literature (Giné et al. 2008, Cole et al. 2009), that it would be better to use additional determinants related to financial literacy, especially insurance knowledge, to capture the relationship between the understanding of insurance concepts and the propensity for lowincome households to participate in different types of microinsurance schemes (Giné et al. 2008, Cole et al. 2009). 
We find that self-employment and unemployment are negatively associated with the use of micro health insurance, and positively related to the uptake of any other insurance. Since we do not know much about the specific causality here, it is important to note that both occupational statuses are related to lower income-earning possibilities, which indicates a lower ability and willingness to pay for micro health.

In line with the literature, we find that wealthier households in Sri Lanka, i.e. households with a higher asset endowment, are more likely to use micro life, health, vehicle or any other form of insurance. Due to the fact that households from the poorest quintile are significantly less likely to participate in a micro life, health, vehicle or any other insurance scheme compared to those from the richest quintile (Table 6), it seems that the poorest households have rather limited access to these microinsurance policies.

From the predictions of the underlying standard neoclassical model and of the model of life insurance demand developed by Lewis (1989), we expected a positive relationship between the degree of risk aversion and the participation in any type of microinsurance. We confirm this expectation, as households perceiving themselves as being more exposed to risk are more likely to participate in a micro health insurance scheme in both specifications (Table 7) and in any other insurance scheme in the first specification. This implies that micro health insurance seems to be seen by the households in Sri Lanka as a risk-coping mechanism and not as an additional risk. 
Table 6: Multivariate Probit Results on the Type of Insurance for Sri Lanka (I)

\begin{tabular}{|c|c|c|c|c|c|c|c|c|}
\hline \multirow[t]{2}{*}{ Variable } & \multicolumn{2}{|c|}{ Life Insurance } & \multicolumn{2}{|c|}{ Health Insurance } & \multicolumn{2}{|c|}{ Vehicle Insurance } & \multicolumn{2}{|c|}{ Other Insurance } \\
\hline & APEs & z-stat. & APEs & z-stat. & APEs & z-stat. & APEs & z-stat. \\
\hline Female head & 0.118 & 0.72 & 0.003 & $2.94 * * *$ & 0.029 & $1.70^{*}$ & -0.011 & $-1.70^{*}$ \\
\hline Household size & 0.066 & $4.12^{* *}$ & 0.0001 & 0.95 & 0.003 & 0.91 & 0.0040 & 1.52 \\
\hline Married head & 0.067 & 0.78 & 0.0002 & $3.20^{* * *}$ & 0.021 & $4.38^{* * *}$ & -0.195 & $-3.87 * * *$ \\
\hline $\begin{array}{l}\text { Ratio of ill } \\
\text { household members }\end{array}$ & 0.381 & $2.08^{* *}$ & -0.00009 & -0.87 & 0.131 & $4.04 * * *$ & -0.002 & -0.25 \\
\hline Age & -0.031 & $-3.72 * * *$ & -0.00004 & $-2.20 * *$ & -0.005 & $-5.15^{* * *}$ & -0.0007 & -0.31 \\
\hline $\begin{array}{l}\text { Age squared } \\
\text { Education of } \\
\text { household head } \\
\text { (base: tertiary } \\
\text { education) }\end{array}$ & 0.0003 & $3.88^{* * *}$ & $5.43 e-07$ & $2.37 * *$ & 0.00006 & $4.69 * * *$ & $-2.17 e-06$ & -0.08 \\
\hline $\begin{array}{l}\text { No or only primary } \\
\text { education }\end{array}$ & 0.467 & $3.66 * * *$ & 0.085 & $3.23^{* * *}$ & 0.027 & $2.55^{* * *}$ & 0.003 & 0.44 \\
\hline $\begin{array}{l}\text { Secondary } \\
\text { Education } \\
\text { Occupation of } \\
\text { household head } \\
\text { (base: formal } \\
\text { employee/employer) }\end{array}$ & 0.103 & $2.55^{* * *}$ & 0.003 & $2.19^{* *}$ & 0.003 & 0.66 & 0.004 & 0.66 \\
\hline $\begin{array}{l}\text { Head is self- } \\
\text { employed }\end{array}$ & 0.077 & 1.51 & -0.0001 & $-1.82^{*}$ & -0.011 & -1.21 & 0.009 & $1.68^{*}$ \\
\hline Head is unemployed & 0.009 & 0.14 & -0.0001 & $-3.01 * * *$ & -0.006 & -0.97 & 0.008 & $1.82 *$ \\
\hline Asset Index & 0.306 & $7.34 * * *$ & 0.011 & $3.79 * * *$ & 0.229 & $5.62^{* * *}$ & 0.015 & $2.26^{* *}$ \\
\hline Land Ownership & 0.049 & 0.88 & -0.0001 & -0.32 & -0.007 & -0.75 & -0.007 & -0.71 \\
\hline Remittance & 0.148 & $1.97 * *$ & -0.0001 & -1.23 & 0.0016 & 0.13 & 0.157 & $2.37 * *$ \\
\hline $\begin{array}{l}\text { Self risk assessment } \\
\text { Household's risk } \\
\text { experience (base: no } \\
\text { risk experience) }\end{array}$ & 0.003 & 0.10 & 0.0001 & $1.95^{* *}$ & 0.004 & 0.72 & 0.004 & $2.30^{* *}$ \\
\hline $\begin{array}{l}\text { Experienced death } \\
\text { of a household } \\
\text { member }\end{array}$ & 0.199 & 1.14 & 0.002 & $3.03 * * *$ & -0.009 & -1.36 & 0.043 & $1.97 * *$ \\
\hline $\begin{array}{l}\text { Experienced severe } \\
\text { illness }\end{array}$ & -0.093 & $-2.30 * *$ & 0.008 & 1.42 & -0.017 & $-4.37 * * *$ & -0.007 & -1.37 \\
\hline $\begin{array}{l}\text { Experienced other } \\
\text { severe shock }\end{array}$ & -0.150 & $-4.06 * * *$ & 0.0001 & 0.51 & -0.039 & $-3.78^{* * *}$ & -0.011 & $-2.61 * * *$ \\
\hline Regional dummies & Yes & - & Yes & - & Yes & - & Yes & - \\
\hline \multirow{2}{*}{$\begin{array}{l}\text { Est. correlation } \\
\text { coeff. }\end{array}$} & $\varrho_{21}=0.05$ & 0.48 & $\varrho_{31}=0.03$ & 0.16 & $\varrho_{41}=-0.13$ & -0.72 & $\varrho_{32}=-0.33$ & $-2.88^{* * *}$ \\
\hline & $\varrho_{42}=0.03$ & 0.21 & $\varrho_{43}=-0.68$ & $-2.20 * *$ & & & & \\
\hline
\end{tabular}

Source: Authors' calculation.

Note: Results of the multivariate probit model are estimated by SML with 20 pseudo-random draws. The z-statistics refer to the estimated coefficients and are based on robust standard errors. Average partial effects (APEs) are calculated with respect to the marginal probability of each type of insurance. The model also includes a constant. Sample size is $\mathrm{N}=330$ observations. *** significant at 1 percent, ${ }^{* *}$ significant at 5 percent, ${ }^{*}$ significant at 10 percent. 
The results confirm that the situation differs according to whether and how the exposure to shocks, i.e. the tested three-risk dummies, is associated with participation in any type of microinsurance. It appears that the experience of a household member's death is related to participation in a micro health and any other kind of insurance in the first specification. The occurrence of a severe illness is negatively related to the use of life and vehicle insurance. The same is true for the experience of any additional other severe shock for the uptake of micro life, vehicle or any other form of insurance in the first specification. Therefore, it seems plausible that households who have experienced a household-related shock - especially the death of a household member - have a higher incentive to secure against the negative outcome of such a shock in the future, whereas after the experience of a household member's illness or any other severe shock the household may not regard insurance as an appropriate risk-management tool, as it may not have the ability or financial resources for the purchase, or access may be restricted.

In order to analyze whether these results are specific to each type of microinsurance studied here, the estimation outcomes of the microinsurance participation decision, i.e. a household's microinsurance participation conditional on MFI membership, as estimated using a conditional probit model, are presented in Table 7 . We find that household size is significantly positively linked to microinsurance participation. The results imply that larger households may have a greater incentive to use their limited resources to obtain risk-reducing effects, as they are commonly more exposed to family-related risks. The age of the household head is significantly related to microinsurance participation. The turning point is 57 years of age, which implies that household heads do not request more insurance with increasing age. One explanation may be that older household heads with MFI membership are less educated and thus less able to understand microinsurance products and markets than their younger counterparts. 
In contrast to our expectations and previous findings, we find for microinsurance uptake which is conditional on a household's MFI enrolment, that no formal, either primary or secondary, education is positively correlated with microinsurance uptake. On the other hand, this implies that the commonly identified constraint of poor understanding of insurance products among lower-educated households might be removed if these households are MFI members; vice versa this might not be related to better understanding but to convincing marketing measures of the MFIs, so that the households could have a poor understanding and so be over-insured. Our results indicate that households from the richest quintile are more likely to participate in microinsurance than those from the poorest quintiles (Table 5), which may indicate reduced accessibility to MFIs by the poor. 
Table7: Institution Membership and Participation Conditional on Membership in Sri Lanka

\begin{tabular}{|c|c|c|}
\hline Variable & $\begin{array}{l}\text { Purchased Conditional } \\
\text { on Membership } \\
\text { (I) }\end{array}$ & $\begin{array}{l}\text { Purchased Conditional } \\
\text { on Membership } \\
\text { (II) }\end{array}$ \\
\hline Female head & -0.0021 & -0.0069 \\
\hline Household size & $0.0069 * * *$ & $0.0055^{* *}$ \\
\hline Age & $-0.0036 * *$ & $-0.0029 * *$ \\
\hline Age squared & $0.00003^{*}$ & $0.00003^{* *}$ \\
\hline \multicolumn{3}{|l|}{$\begin{array}{l}\text { Education of household head (base: tertiary } \\
\text { education) }\end{array}$} \\
\hline No or only primary education & $0.6278^{* * *}$ & 0.2097 \\
\hline Secondary Education & 0.0118 & 0.0075 \\
\hline \multicolumn{3}{|l|}{$\begin{array}{l}\text { Occupation of household head (base: formal } \\
\text { employee/employer) }\end{array}$} \\
\hline Head is self-employed & 0.0125 & 0.0098 \\
\hline Head is unemployed & 0.0096 & 0.0039 \\
\hline Asset Index & $0.0171 * * *$ & - \\
\hline \multicolumn{3}{|l|}{ Asset Quintiles (base: richest 20\%) } \\
\hline Quintile 1 & - & $-0.2621 * * *$ \\
\hline Quintile 2 & - & $-0.0251 * * *$ \\
\hline Quintile 3 & - & $-0.0781 * * *$ \\
\hline Quintile 4 & - & 0.0033 \\
\hline Land Ownership & -0.0017 & $0.0046^{* *}$ \\
\hline Remittance & 0.5448 & $0.6719 * *$ \\
\hline Self risk assessment & $0.0031 * *$ & 0.0017 \\
\hline \multicolumn{3}{|l|}{$\begin{array}{l}\text { Household's risk experience (base: no risk } \\
\text { experience) }\end{array}$} \\
\hline Experienced death of a household member & 0.1648 & 0.0361 \\
\hline Experienced severe illness & -0.0029 & $-0.0043^{* *}$ \\
\hline Experienced other severe shock & $-0.0422^{*}$ & $-0.0419 *$ \\
\hline Regional Dummies & Yes & Yes \\
\hline Observations & 304 & 304 \\
\hline
\end{tabular}

Source: Authors' calculation.

Note: Probit model coefficients are normalized to display marginal effects. ${ }^{* * *}$ significant at 1 percent, ${ }^{* *}$ significant at 5 percent, $*$ significant at 10 percent.

Consistent with the neoclassical model with CARA utility and symmetric information presented by Giné, Townsend and Vickery (2008), we find that households with MFI members perceiving themselves as riskier are significantly more likely to have microinsurance. This indicates that households may not see insurance as an additional risk which is related to mistrust in the MFI and its staff or to misunderstanding of the offered microinsurance products. In contradiction to earlier findings by Giesbert et al. (2011), we find a positive association of remittances with 
microinsurance uptake. Further, we find for the three risk-dummies that households who experienced an additional shock are significantly less likely to use microinsurance.

\section{Conclusions}

The findings of this study show uptake of different kinds of microinsurance by the same population. We find that self-employment and unemployment are negatively associated with the use of micro health insurance, and positively related to the uptake of any other insurance. Household size is positively associated with the use of micro life insurance - presumably due to an intended bequest motive - and any other form of microinsurance in Sri Lanka. The femaleheadship of a household is positively associated with the use of micro health insurance, which is also true for married heads of households. Since the educational level of the household head has emerged as a strong determinant of a household's microinsurance participation, the implementation and promotion of insurance education measures by the MFIs is recommended, in order to improve a household's understanding of and knowledge about insurance. This would reduce mistrust in the providing institutions, among both target groups and existing clients in the community. In the long run, this may lead to more financially capable individuals and households who can make informed decisions about microinsurance participation, especially in rural communities. The paper further indicate the need for inclusive microinsurance products with composite packages for greater financial inclusion of the poor. Broadly, the findings of the paper indicate that although existing programmes have the potential to function as effective ex ante risk-management strategies, there is still a strong need to build up an insurance culture among the poor in Sri Lanka. 


\section{References}

Akerlof, George A. (1970): The market for "lemons", Quality uncertainty and the market mechanism, Quarterly Journal of Economics, 84: 488-500.

Armendáriz, Beatriz and Jonathan Morduch (2005): The Economics of Microfinance, Chapter 6 Savings and Insurance, Cambridge, Mass. and London: The MIT Press.

Arun, Thankom, Mirko Bendig and Shoba Arun (2012): Bequest Motives and Determinants of Micro Life Insurance in Sri Lanka, World Development 40(8), pp. 1700-1711.

Arun, Thankom and Mirko Bendig (2010): Participation in Micro Life Insurance in Sri Lanka: The Role of Bequest Motives, IZA Discussion Paper, No. , September 2010, Bonn: Institute for the Study of Labor.

Asfaw, A. (2003): Cost of Illness, demand for medical care, and the prospect of community health insurance schemes in the rural areas of Ethiopia, Frankfurt: Peter Lang Eds.

Asian Development Bank (ADB) (2006): Technical Assistance to Sri Lanka for Microinsurance Sector Development- Supply Assessment of Microinsurance Products. Australia: Cambridge Centre for Public Policy Development.

Barsky, R.B., Juster F. Th., Kimball M.S. and Spapiro M.D. (1997): Preference parameters and behavioral heterogeneity: an experimental approach in the health and retirement study, in: Quarterly Journal of Economics, 112: 537-579.

Bartus, Tamás (2005): Estimation of marginal effects using margeff, in: The Stata Journal, 5(3): 309 329.

Beck, Thorsten and Webb, Jan (2002): Economic, Demographic, and Institutional Determinants of Life Insurance Consumption Across Countries, The World Bank Economic Review, 17: 51-88.

Bendig, Mirko and Thankom Arun (2011). Microfinancial Services and Risk Management: Evidences From Sri Lanka, Journal of Economic Development, 36(4), pp.97-126

Bendig, Mirko and Thankom Arun (2011). Enrolment in Micro Life and Health Insurance:

Evidences from Sri Lanka, IZA DP No. 5427, pp.1-27.

Bhat, Ramesh and Nishant Jain (2006): Factoring Affecting the Demand for Health Insurance in a Micro Insurance Scheme, Working Paper No. 2006-07-02, Ahmedabad: Indian Institute of Management. Browne, Mark J. and Kim, Kihong (1993): An International Analysis of Life Insurance Demand, 
Journal of Risk and Insurance, 60: 616-634.

Browne, Mark J. and Helen I. Doerpinghaus (1993): Information Asymmetries and Adverse Selection in the Market for Individual Medical Expense Insurance, The Journal of Risk and Insurance, 60: 300-312. Cameron, Colin A. and Pravin K. Trivedi (2009): Microeconometrics Using Stata, First Edition, College Station: Stata Press.

Capellari, Lorenzo and Stephen P. Jenkins (2003): Multivariate probit regression using simulated maximum likelihood, in: The Stata Journal, 3(3): 278-294.

Cawley and Phillipson, 1999: An Empirical Examination of Information Barriers to Trade in Insurance, American Economic Review, 89(4): 827-846.

Chankova, Slavea, Sulzbach, Sara and Diop, Francois (2008): Impact of mutual health organizations: evidence from West Africa, Health Policy and Planning, 23(4): 264-276.

Cole, Shawn, Giné, Xavier, Tobacman, Jeremy, Topalova, Petia, Townsend, Robert M. and James Vickery (2009): Barriers to Household Risk Management: Evidence from India, Havard Business School Finance Working Paper 09/116, Boston: Harvard Business School.

Churchill, Craig (ed.) (2006): Protecting the Poor. A Micro Insurance Compendium, Genf: ILO. Datta, Dipankar (2004): Microcredit in rural Bangladesh. Is it reaching the poorest?, in: Journal of Microfinance, 6(1): 55-81.

Dercon, Stefan (2002): Income Risk, Coping Strategies, and Safety Nets, in: World Bank Research Observer, 17(2): 141-166.

Dror, D.M., Radermacher, R. and Koren, R. (2007): Willingness to Pay for Health Insurance Among Rural and Poor Persons: Field Evidence from Seven Micro Health Insurance Units in India, Health Policy, 82(1).

Eling, Martin, Shailee Pradhan and Joan T Schmit (2014) he Determinants of Microinsurance

Demand, The Geneva Papers on Risk and Insurance - Issues and Practice, 39(2) : 224-263

Enarsson, Sven and Wirén, Kjell (2006): ALMAO and YASIRU Sri Lanka, CGAP Working Group on Microinsurance - Good and Bad Practices - Case Study No 21.

Fafchamps, Marcel, and Susan Lund (2003): Risk-sharing networks in rural Philipines, Journal of Development Economics 71 (2): 261-287.

Giesbert, Lena, Steiner, Susan und Mirko Bendig (2011): Participation in Micro Life Insurance and the Use of Other Financial Services in Ghana, Journal of Risk and Insurance, 78(1), pp. 7-35. 
Giné, Xavier, Robert Townsend und James Vickery (2008): Patterns of rainfall insurance participation in rural India, in: The World Bank Economic Review, 22(3): 539-566.

Giné, Xavier and Dean Yang (2009): Insurance, Credit and Technology Adoption: Field Experimental Evidence from Malawi, Journal of Development Economics 89 (1), pp. 1-11.

Greene, William H. (2003): Economic analysis, Third edition, Upper Saddle River: Prentice Hall. GTZ (2009): Microfinance Industry Report Sri Lanka 2009, Produced by GTZ ProMiS in collaboration with The Banking With The Poor Network, Gesellschaft für technische Zusammenarbeit (GTZ): Eschborn.

Hamid, Syed Abdul, Roberts, Jennifer and Paul Mosley (2010): Can Micro Health Insurance Reduce Poverty? Evidence from Bangladesh, Sheffield Economic Research Paper Series, No. 2010001, Sheffield: University of Sheffield.

Hulme, David and Paul Mosley (1997): Finance for the poor of the poorest? Financial innovations, poverty and vulnerability, in: Geoffrey Wood and Iffath Sharif (eds.): Who needs credit? Poverty and finance in Bangladesh, Dhaka: University Press: 96-129.

Hurd, Michael D. (1987): Savings of the Elderly and Desired Bequests, in: American Economic Review, 77, pp. 298-312.

Hurd, Michael D. (1994): Measuring the Bequest Motive: The Effect on Children on Saving by the Elderly in the United States, in: Toshiaki Tachibanaki (eds.): Savings and Bequests, Michigan: The University of Michigan Press, pp. 111-136.

Inkmann, Joachim and Alexander Michaelides (2010): Can the Life Insurance Market Provide Evidence for a Bequest Motive?, Working Paper, Central Bank of Cyprus, London School of Economics, 2010.

Ito, Seiro and Hisaki Kono (2010): Why is the Take-up of Microinsurance so Low? Evidence from a Health Insurance Scheme in India, The Developing Economies 48 (1), pp. 74-101.

Jones, Andrew (2007): Applied econometrics for health economists: A practical guide, Second Edition, Oxford: Radcliffe Publishing Ltd.

Jütting, Johannes (2003): Do Community-based Health Insurance Schemes Improve Poor People’s Access to Health Care? Evidence From Rural Senegal, in: World Development, 32(2): 273-288.

Khandker, Shahidur R. (1998): Fighting poverty with microcredit: experience in Bangladesh, New York:

Oxford University Press for the World Bank.

Kis-Katos, Krisztina (2007): The work-schooling trade-off of Indian children, mimeo. 
Lewis, Frank (1989): Dependents and the Demand for Life Insurance, American Economic Review, 79: 452-466.

Kurosaki, Takashi and Marcel Fafchamps (2002): Insurance market efficiency and crop choices in Pakistan, Journal of Development Economics 67 (3): 419-453.

Mas-Colell, Andreu, Whinston, Michael D. and Jerry R. Green (1995): Microeconomic Theory, New York and Oxford: Oxford University Press.

McCord; Michael J. (2001): Health care microinsurance - case studies from Uganda, Tanzania, India and Cambodia, Small Enterprise Development, 12(1): 25-38.

Morduch, Jonathan (1995): Income Smoothing and Consumption Smoothing, in: Journal of Economic Perspectives, 9(3): 103-114.

Navajas, Sergio et al. (2000) : Microcredit and the poorest of the poor. Theory and evidence from Bolivia, in: World Development, 28(2): 333-346.

Outreville, Francois J. (1996): Life Insurance Markets in Developing Countries, Journal of Risk and Insurance, $63: 263-278$.

Pauly, M.V. (2004): The demand for health insurance: insights from theory and voluntary markets in less-developed countries, Background paper presented at Wharton Impact Conference on Voluntary Health Insurance in Developing Countries, March 15-16, University of Pennsylvania, http://hc.wharton.upenn.edu/impactconference/index.html (accessed on 07.11.2008).

Rothschild, Michael and Joseph E. Stiglitz, 1976: Equilibrium in Competitive Insurance Markets: An Essay on the Economics of Imperfect Information, Quarterly Journal of Economics, 90: 630-49.

Siegel, Paul B., Alwang, Jeffrey and Sudharshan Canagarajah (2001): Viewing Microinsurance as a Social Risk Management Instrument, Social Protection Discussion Paper No. 0116, World Bank: Washington DC.

Townsend, Robert (1995): Consumption Insurance: An Evaluation of Risk-Bearing Systems in Low Income Economies, in: Journal of Economic Perspectives, 9(3): 83-102.

Truett, Dale B. and Truett, Lila J. (1990): The Demand for Life Insurance in Mexico and the United States: A Comparative Study, Journal of Risk and Insurance, 57: 321-328.

Waters, H. (1999): Measuring the impact of health insurance with a correction for selection bias a case study of Ecuador. Health Economics and Econometrics, 8: 473-483.

Worldbank (2008): Finance for All? Policies and Pitfalls in Expanding Access, World Bank Policy Research 
Report, Washington DC: World Bank.

Zeller, Manfred and Manohar Sharma (2002): Access to and demand for financial services by the rural poor: A multicountry synthesis, in: Manfred Zeller and Richard L. Meyer (eds.): The triangle of microfinance: Financial sustainability, outreach, and impact, Baltimore and London: Johns Hopkins University Press: 19-45. 


\section{Appendix}

Table 8: Definition of Explanatory Variables for Sri Lanka

\begin{tabular}{|c|c|}
\hline Variable & Description \\
\hline Female head & Dummy variable, 1 if household is headed by a female, 0 otherwise \\
\hline Household size & Household size \\
\hline Married head & Dummy variable, 1 if household head is married, 0 otherwise \\
\hline $\begin{array}{l}\text { Ratio of ill household } \\
\text { members }\end{array}$ & $\begin{array}{l}\text { Ratio of ill household members in the previous } 12 \text { months to the total number of household } \\
\text { members }\end{array}$ \\
\hline Age & Age of the household head \\
\hline Age squared & Age of the household head squared \\
\hline $\begin{array}{l}\text { No or only primary } \\
\text { education }\end{array}$ & Dummy variable, 1 if household has no or only primary education, 0 otherwise \\
\hline Secondary education & Dummy variable, 1 if household has secondary education, 0 otherwise \\
\hline $\begin{array}{l}\text { Head is self- } \\
\text { employed }\end{array}$ & $\begin{array}{l}\text { Dummy variable, } 1 \text { if household head is self-employed or a contractual worker in either } \\
\text { agriculture or non-agricultural activities, } 0 \text { otherwise }\end{array}$ \\
\hline Head is unemployed & $\begin{array}{l}\text { Dummy variable, } 1 \text { if household head is not employed due to young or old age, disability, or } \\
\text { similar reasons, } 0 \text { otherwise }\end{array}$ \\
\hline Assets & $\begin{array}{l}\text { Assets (for Sri Lanka: motorcycle, bicycle, jewellery, refrigerator, sewing machine, electric iron, } \\
\text { water heater, fan, TV, DVD, radio, fixed phone, mobile phone, main source of drinking, toilet } \\
\text { facility, main source of lighting) owned by the household and was not purchased by a loan, } \\
\text { index created by factor analysis }\end{array}$ \\
\hline \multirow[t]{2}{*}{ Quintile 1-5 } & $\begin{array}{l}\text { Five asset index quintiles labeled as Quintile } 1 \text { to } 5 \text {, Quintile } 1 \text { is the poorest quintile and } \\
\text { Quintile } 5 \text { is the quintile of households with the highest asset endowment. }\end{array}$ \\
\hline & $\begin{array}{l}\text { Dummy variables, } 1 \text { if household belong to the asset index quintile, } 0 \text { otherwise. (Quintile } 5 \\
\text { functions as reference category) }\end{array}$ \\
\hline Land ownership & Dummy variable, if the household owns any land, 0 otherwise \\
\hline Remittance & $\begin{array}{l}\text { Dummy variable, } 1 \text { if household receives remittances from former household members who } \\
\text { have migrated, } 0 \text { otherwise }\end{array}$ \\
\hline $\begin{array}{l}\text { Household's self- } \\
\text { perception of risk }\end{array}$ & $\begin{array}{l}\text { Household's assessment of own risk situation (subjective exposure to health shocks, weather } \\
\text { and environment related shocks, and economic shocks compared with neighbours, own rating } \\
\text { of willingness to take risks), index created by factor analysis }\end{array}$ \\
\hline $\begin{array}{l}\text { Experienced } \\
\text { Death of a household } \\
\text { member }\end{array}$ & $\begin{array}{l}\text { Dummy variable, } 1 \text { if household experienced the death of a household member in the last five } \\
\text { years and this shock had serious consequences, i.e. household needed more than one month to } \\
\text { recover, } 0 \text { otherwise }\end{array}$ \\
\hline $\begin{array}{l}\text { Experienced } \\
\text { Illness of a household } \\
\text { member }\end{array}$ & $\begin{array}{l}\text { Dummy variable, } 1 \text { if household experienced the illness of a household member in the last five } \\
\text { years and this shock had serious consequences, i.e. household needed more than one month to } \\
\text { recover, } 0 \text { otherwise }\end{array}$ \\
\hline $\begin{array}{l}\text { Experienced other } \\
\text { severe shock }\end{array}$ & $\begin{array}{l}\text { Dummy variable, } 1 \text { if household experienced a severe shock }{ }^{6} \text { other than the previous } \\
\text { described shock in the last five years and this shock had serious consequences, i.e. household } \\
\text { needed more than one month to recover from the economic consequences, which is in this } \\
\text { case to reach the same income earnings level as before the shock occurred, } 0 \text { otherwise }\end{array}$ \\
\hline $\begin{array}{l}\text { Locational/Regional } \\
\text { dummies }\end{array}$ & $\begin{array}{l}\text { Dummy variables, } 1 \text { if household resides in the region, and } 0 \text { otherwise. Nine dummy variables } \\
\text { (Western, Southern, North Western, North, Central, Sabara, North Central, Uva and Western } \\
\text { region) are used in the analysis. The Central region functions a reference category. }\end{array}$ \\
\hline
\end{tabular}

Source:Authors' illustration.

\footnotetext{
${ }^{6}$ A shock is here understood as an unexpected or unpredictable event that affects a household negatively. A shock is severe if it affects the household income generating abilities in such amount that the household is in danger to not cover its day to day exspenses at least for a period of one month.
} 
Table 9: Multivariate Probit Results on the Type of Insurance for Sri Lanka (II)

\begin{tabular}{|c|c|c|c|c|c|c|c|c|}
\hline \multirow[t]{2}{*}{ Variable } & \multicolumn{2}{|c|}{ Life Insurance } & \multicolumn{2}{|c|}{ Health Insurance } & \multicolumn{2}{|c|}{ Vehicle Insurance } & \multicolumn{2}{|c|}{ Other Insurance } \\
\hline & APEs & z-stat. & APEs & z-stat. & APEs & z-stat. & APEs & z-stat. \\
\hline Female head & 0.052 & 0.36 & 0.0009 & $2.32^{* *}$ & -0.005 & -0.08 & -0.014 & $-2.32 * *$ \\
\hline Household size & 0.049 & $2.85^{* * *}$ & 0.00008 & 0.63 & 0.001 & 0.40 & 0.004 & 1.35 \\
\hline Married head & 0.043 & 0.42 & 0.0001 & 0.91 & 0.018 & $2.22^{* *}$ & -0.169 & $-5.32 * * *$ \\
\hline $\begin{array}{l}\text { Ratio of ill } \\
\text { household members }\end{array}$ & 0.346 & 1.52 & -0.00009 & -1.23 & 0.143 & $9.39 * * *$ & -0.005 & -0.70 \\
\hline Age & -0.034 & $-3.95^{* * *}$ & -0.00006 & $-2.84 * * *$ & -0.004 & $-6.33 * * *$ & -0.0004 & -0.15 \\
\hline $\begin{array}{l}\text { Age squared } \\
\text { Education of } \\
\text { household head } \\
\text { (base: tertiary } \\
\text { education) }\end{array}$ & 0.0004 & $4.12 * * *$ & $7.98 \mathrm{e}-07$ & $3.37 * * *$ & 0.00004 & $5.35^{* * *}$ & $-7.05 e-06$ & -0.22 \\
\hline $\begin{array}{l}\text { No or only primary } \\
\text { education }\end{array}$ & 0.358 & $3.02 * * *$ & 0.049 & $3.97 * * *$ & 0.025 & $1.73^{*}$ & 0.003 & 0.31 \\
\hline $\begin{array}{l}\text { Secondary } \\
\text { Education } \\
\text { Occupation of } \\
\text { household head } \\
\text { (base: formal } \\
\text { employee/employer) }\end{array}$ & 0.079 & $2.44 * *$ & 0.0024 & $2.22 * *$ & 0.0009 & 0.20 & 0.006 & 0.91 \\
\hline $\begin{array}{l}\text { Head is self- } \\
\text { employed }\end{array}$ & 0.085 & $1.79 *$ & -0.0003 & $-2.85^{* * *}$ & -0.009 & $-1.90^{*}$ & 0.013 & $1.84 *$ \\
\hline $\begin{array}{l}\text { Head is unemployed } \\
\text { Asset Index } \\
\text { Asset Quintiles } \\
\text { (base: the richest } \\
20 \% \text { ) }\end{array}$ & 0.006 & $\begin{array}{l}0.01 \\
-\end{array}$ & -0.0003 & $\begin{array}{l}-5.09 * * * \\
-\end{array}$ & -0.0003 & -0.05 & 0.011 & $\begin{array}{l}2.12^{*} \\
-\end{array}$ \\
\hline Quintile 1 & -0.248 & $-8.50 * * *$ & -0.001 & $-4.27 * * *$ & -0.063 & $-6.59 * * *$ & -0.017 & $-1.91 *$ \\
\hline Quintile 2 & -0.224 & $-5.67 * * *$ & -0.001 & $-3.55^{* * *}$ & -0.029 & $-6.31 * * *$ & -0.018 & $-1.79 *$ \\
\hline Quintile 3 & -0.182 & $-5.12^{* * *}$ & -0.0005 & $-5.04 * * *$ & -0.029 & $-7.88 * * *$ & -0.013 & -1.07 \\
\hline Quintile 4 & 0.006 & 0.20 & -0.0003 & $-3.67 * * *$ & -0.008 & -1.33 & -0.0003 & -0.02 \\
\hline Land Ownership & 0.067 & 1.29 & -0.00004 & -0.14 & 0.006 & 1.11 & -0.011 & -1.08 \\
\hline Remittance & 0.119 & 0.94 & -0.0001 & -0.91 & 0.001 & 0.18 & 0.132 & $1.94^{* *}$ \\
\hline $\begin{array}{l}\text { Self risk assessment } \\
\text { Household's risk } \\
\text { experience (base: no } \\
\text { risk experience) }\end{array}$ & 0.009 & 0.30 & 0.0002 & $3.00 * * *$ & 0.010 & 1.38 & 0.004 & 1.59 \\
\hline $\begin{array}{l}\text { Experienced death } \\
\text { of a household } \\
\text { member }\end{array}$ & 0.119 & 0.87 & -0.00009 & -0.33 & -0.002 & -0.28 & 0.019 & 1.02 \\
\hline $\begin{array}{l}\text { Experienced severe } \\
\text { illness }\end{array}$ & -0.078 & -1.61 & 0.006 & 1.28 & -0.016 & $-3.74 * * *$ & -0.089 & -0.94 \\
\hline $\begin{array}{l}\text { Experienced other } \\
\text { severe shock }\end{array}$ & -0.167 & $-4.20 * * *$ & -0.0001 & -0.19 & -0.029 & $-3.53 * * *$ & -0.019 & $-2.23^{* *}$ \\
\hline Regional dummies & Yes & - & Yes & - & Yes & - & Yes & - \\
\hline \multirow{2}{*}{$\begin{array}{l}\text { Est. correlation } \\
\text { coeff. }\end{array}$} & $\varrho 21=0.08$ & 0.52 & $\varrho_{31}=.0 .05$ & -0.23 & $\begin{array}{l}\varrho 41=- \\
0.14\end{array}$ & -1.26 & $\begin{array}{l}\varrho_{32}=- \\
0.29\end{array}$ & -1.35 \\
\hline & $\varrho_{42}=0.03$ & 0.29 & $\varrho 43=-0.73$ & $-3.40^{* * *}$ & & & & \\
\hline
\end{tabular}

Source: Authors' calculation.

Note: Results of the multivariate probit model are estimated by SML with 20 pseudorandom draws. The z-statistics refer to the estimated coefficients and are based on robust standard errors. Average partial effects (APEs) are calculated with respect to the marginal probability of each type of insurance. The model also includes a constant. Sample size is $\mathrm{N}=330$ observations. *** significant at 1 percent, ${ }^{* *}$ significant at 5 percent, ${ }^{*}$ significant at 10 percent. 